\title{
Rhabdomyolysis following moderate exercise
}

Maj DR Wilson

MRCP(UK),RAMC

Specialist Registrar

Royal Defence Medical College, Horton Block, HMS Dolphin, Gosport, Hants POI2 $2 A B$

SUMMARY: Raised levels of serum muscle enzyme activity are frequently seen following unaccustomed or prolonged strenuous exercise. Following particularly severe exercise, muscle enzyme levels can be extremely high and are occasionally associated with rhabdomyolysis. A case of rhabdomyolysis following a moderate degree of accustomed exercise in a fit young soldier is reported and discussed.

\section{Case History}

A 23 year old soldier was admitted as a surgical emergency with a 24 hour history of bilateral lower abdominal pain which radiated into both groins and testes. He had no other symptoms. On further questioning he gave a history of an exercise session 48 hours previously, during which he spent one hour performing abdominal wall strengthening exercises. This type and degree of exercise was not unusual for him but he had felt abnormally stiff and sore in the abdominal wall the following day. He had not taken part in any other form of physical activity.

He had no past medical history of note, was on no medication and denied any abuse of alcohol or drugs including anabolic steroids. He had not recently travelled abroad but had been given Hepatitis A vaccination 2 weeks previously. He had no risk factors for Hepatitis B, was married and his wife was in good health.

Examination revealed only bilateral iliac fossa tenderness with no guarding or rebound tenderness. He was apyrexial and there was no jaundice or any other stigmata of liver disease. Full Blood Count and Urea \& Electrolytes were normal. Liver Function Tests and muscle enzyme results are shown in Table 1 (admission). Urinalysis was strongly positive for blood but no red blood cells were seen on microscopy, confirming the likelihood of Myoglobinuria.

Table 1

\begin{tabular}{|c|c|c|c|c|c|}
\hline & Units & $\begin{array}{c}\text { Normal } \\
\text { Range }\end{array}$ & Admission & Day 2 & Day 5 \\
\hline Bilirubin & umol/1 & $3-24$ & 21 & 13.5 & 9 \\
\hline Alkaline Phosphatase & $\mathrm{U} / 1$ & $70-250$ & 71 & 68 & 67 \\
\hline $\begin{array}{c}\text { Aspartate } \\
\text { Aminotransferase }\end{array}$ & $\mathrm{U} / 1$ & $16-41$ & 13 & 10 & 11 \\
\hline $\begin{array}{c}\text { Alanine } \\
\text { Aminotransferase }\end{array}$ & $\overline{\mathrm{U}} / \mathrm{1}$ & $5-35$ & 531 & 404 & 125 \\
\hline $\begin{array}{c}\text { Gamma Glutamyl } \\
\text { Transferase }\end{array}$ & $\mathrm{U} / \mathrm{l}$ & $11-51$ & 171 & 156 & 115 \\
\hline \begin{tabular}{c} 
Creatine Kinase (CK) \\
\hline CK-MB fraction
\end{tabular} & $\mathrm{U} / \mathrm{l}$ & $25-171$ & 31,267 & 23,467 & 2,316 \\
\hline \begin{tabular}{c} 
Lof CK \\
\hline $\begin{array}{c}\text { Lactate } \\
\text { Dehydrogenase }\end{array}$
\end{tabular} & $\mathrm{U} / 1$ & $70-250$ & $<0.5$ & $<0.5$ & $<0.5$ \\
\hline
\end{tabular}

He was referred for medical management and was treated with analgesia and a period of observation and investigation. Serial blood tests are shown in Table 1. Leptospiral serology was negative and 24 hour Creatinine Clearance was normal at $125 \mathrm{ml} / \mathrm{min}$, Electrocardiograph was unremarkable. The pain settled over 2 - 3 days and he was discharged feeling completely well 6 days after admission. He remained well on follow-up.

\section{Discussion}

Delayed Onset Muscle Soreness (DOMS) is a frequent五 consequence of strenuous exercise, usually occurring after⿳亠口冋 a delay of $24-72$ hours (1). It is often accompanied by atransient rise in serum muscle enzyme activity, particularly Creatine Phosphokinase (CPK) (2). There is great inter-o subject variability in the levels of CPK recorded after similar exercise activity, but levels of 5,000 $\mathrm{U} / \mathrm{l}$ are rarely exceeded in healthy individuals (3). It is known that repeated bouts of exercise attenuate the subsequent CPK response to exercise, probably due to incomplete repair of damaged muscle fibres (4).

Rhabdomyolysis is diagnosed when myoglobinuria is detected in the presence of raised serum muscle enzymes. It is a frequent accompaniment to DOMS and has been found in up to $40 \%$ of military recruits in the first 6 days of a vigorous fitness training programme (5). Acute renal failure is a rare consequence, occurring in one of 35 patients with rhabdomyolysis in one series (6), although rates of $5-40 \%$ have been reported by others (7).

Massive rises in CPK with evidence of rhabdomyolysis are well documented following exercise of unaccustomed type or severity and in exertional heat stroke $(1,7)$. They are, however, rarely seen in well-trained individuals undertaking degrees of exercise to which they are accustomed $(8,9,10)$, such as in this case, although even a high level of fitness cannot protect against muscle overuse (11).

Opinion is divided on whether the occurrence of DOMS can be predicted by the intensity or duration of the exercise performed $(6,9)$. It appears clearer, however, that the form of exercise taken does affect the likelihood of muscle damage with eccentric exercise (actively resisting the 
lengthening of muscle) being implicated more than concentric (muscle tension and shortening) or isometric (muscle tension without shortening) exercise $(8,12,13)$. This is probably due to a greater mechanical stress per muscle fibre (11). Repetitive intensive isometric exercise and prolonged strenuous endurance exercise have also been reported to cause DOMS (1).

Most soldiers are highly physically trained and are accustomed to both intense and prolonged exercise. The occurrence of rhabdomyolysis following a moderate level of exercise in such an individual is very unusual (10). It is likely that this arose as a complication of the intense and prolonged exercising of a single muscle group. Intercurrent illness is another possible factor although he reported no relevant symptoms. Hepatitis A vaccine had been administered 2 weeks previously but he had suffered no ill effects and no reports suggesting any relation have been discovered in a search of the literature.

The implications of this report include the need for soldiers to be instructed on safe and sensible approaches to exercise in order to prevent muscle damage and subsequent time away from duties, as well as the potentially more serious consequences of rhabdomyolysis and acute renal failure.

\section{REFERENCES}

1. Miles MP, Clarkson PM. Exercise-induced muscle pain, soreness and cramps. (Review) J Sports Med Phys Fitness 1994; 34(3): 203-16.

2. alzawa H, Morita K, Minami H, Sasaki N, Tobise K. Exertional rhabdomyolysis as a result of strenuous military training. J Neurol Sci 1995; 132(2): 239-240.
3. EPSTEIN Y. Clinical significance of serum creatine phosphokinase activity levels following exercise. Isr Med Sci 1995; 31(11): 657-658.

4. MORTON RH, CARTER MR. Elevated serum enzyme activity: an explanation-based model. $J$ Appl Physio 1992; 73(5): 192-200.

5. Olerud JE, HOMER LD, CARroll HW. Incidence of? acute exertional rhabdomyolysis. Arch Intern Mes 1976; 136: 692-697.

6. Sinert R, Kohl L, Rainone T, Scalea T. Exercise induced rhabdomyolysis. (Review) Ann Emerg Med 1994; 23(6): 1301-1306.

7. Soni SN, MCDonald E, Marino C. Rhabdomyolysis after exercise. Postgrad Med 1993; 94(6): 128-132.

8. LU SS, WU SK, CHEN JJ. The effects of heavy eccentric contractions on serum Creatine Kinase levels. Chin Physiol 1992; 35(1): 35-44.

9. Karamizrak SO, Ergen E, Tore IR, Akgun N Changes in serum creatine kinase, lactate deyhdrogenase and aldolase activities following supramaximal exercise in athletes. $J$ Sports Med Phy $\overrightarrow{s \vec{s}}$ Fitness 1994; 34(2): 141-146.

10. HURLEY JK. Severe rhabdomyolysis in well conditioned, athletes. Milit Med 1989; 154(5): 244-5.

11. KUIPERS H. Exercise-induced muscle damage. (Revieyg Int J Sports Med 1994; 15(3): 132-125.

12. Nosaka K, Clarkson PM, Apple FS. Time courseğo serum protein changes after strenuous exercise of forearm flexors. I Lab Clin Med 1992; 119(2): 183-1

13. SCHNeider CM, Dennehy CA, Rodearmel HAYWARD JR. Effects of physical activity on crea phosphokinase and the isoenzyme Creatine Kinase- 